\title{
Review
}

\section{The future and its enemies: In defense of political hope}

\author{
Daniel Innerarity, translated by Sandra Kingery \\ Stanford University Press, Stanford, CA, 2012, 152pp., \$21.95, \\ ISBN 978-0804775571.
}

Contemporary Political Theory (2014) 13, e4-e7. doi:10.1057/cpt.2013.32

It is possible to classify political regimes according to the implicit rules they follow in the construction of temporality. Hereditary monarchy strives to establish an uninterrupted continuity between the past and the future by means of royal succession. 'The King is dead! Long live the King!' means above all that, despite empirical accidents such as the death of a physical person, the political fabric of monarchy suffers no ruptures; the future is the past with a slightly different face. Aristocracies not guided by the meritocratic principle fall back on the same foundation of natural reproduction, which they transform into the mechanism of political self-perpetuation. Curiously enough, tyranny and oligarchy - the respective deficient versions of monarchy and aristocracy, identified by Aristotle in his Politics - are incapable of legitimately guaranteeing their own future, which is why they must rely so heavily on brute physical and economic force. Only in the case of democracy do we come across a political system that is constitutively open future, insofar as the limitation of terms in office introduces a healthy dose of indeterminacy and discontinuity into its workings.

Daniel Innerarity is not the first political philosopher to have paid attention to the complicated relation of democracies to their future. Most famously, Jacques Derrida already accentuated the temporality of 'democracy-to-come' in his 2003 book Rogues: Two Essays on Reason. However, Innerarity is the sole thinker to date who is attuned to the futurity of actually existing democracies, which he sets in the context of changing social rhythms, new demands of the knowledge society and issues of environmental justice.

For those not yet familiar with his work, Daniel Innerarity is a Basque political philosopher who was included by the French magazine Le Nouvel Observateur in its list of the 25 most influential thinkers in the world, alongside Martha Nussbaum and Charles Taylor. His main line of investigation thus has focused on 'democratic complexity'. Under this general heading, a trilogy of books has been

(C) 2014 Macmillan Publishers Ltd. 1470-8914 Contemporary Political Theory Vol. 13, 3, e4-e7 
published: The Future and its Enemies (2009), The Democracy of Knowledge (2011), and $A$ World of Everybody and Nobody, forthcoming in the English translation next year.

In the first book of the trilogy, reviewed here, Innerarity masterfully combines the insights of a seasoned philosopher with the hands-on analyses of a political scientist or a sociologist. Further, his multidisciplinary methodology has a direct bearing on the content of his argument. Adopting the motto 'the future as a place of liberty' (p. 5), he moderates a more abstract theme with the study of social, economic and political conditions of possibility for (as well as threats to) a uniquely democratic future.

One of the serious perils democracies face is that they do not know how to cope with the freedom at their disposal. The notion of 'escape from freedom', coined by Eric Fromm, becomes relevant to the entire body politic. Given 4- or 5-year election cycles, long-term public interest is neglected at the expense of immediate political goals (pp. 9-10). Political decisions and practices lose their active dimension and are guided by the reactive imperative of 'putting out fires', or tackling 'immediate pressures, such as protests or elections' (p. 29). Innerarity's alternative to this narrow-minded vision is what he terms chronopolitics, or 'a government of time' (p. 77). It is worth considering the sense of this expression, which holds the key to Innerarity's overall approach.

The government of time is by no means synonymous with the kind of total control that underpins the projects of planning in the political or economic spheres. The complexity of modern societies requires the ability to navigate between the Scylla of absolute determinacy and the Charybdis of sheer indeterminacy. Where human actors fall into either extreme, a passive attitude reigns supreme, 'there is nothing to decide', and therefore politics is 'somewhat irrelevant' (p. 47). Conversely, the government of time takes the shape of 'a more or less reasonable management of doubt' (p. 46) - not a precise calculation of probabilities but a decision (in the full sense of the word) that respects the relative indeterminacy of the future neither dissolving it in a continuation of the present nor sanctifying it as the advent of the unknown Other. Here and elsewhere throughout his study, Innerarity will opt out for a middle path between two extremes, perhaps unwittingly displaying a great affinity to Aristotelian ethics.

Another significant instance of reasonable balance struck on the shaky terrain of political future is the democratic eurhythmics adumbrated 'between idiorrhythm and totalitarian synchronization' (p. 85). The complexity characteristic of modernity is largely temporal, with uneven global development accompanied by a de-synchronization among systems (of law, technology, the media and so forth) and the lives of individuals, generations and social groups (p. 82). When, verging on idiorrhythmics, the paces in question fall out of sync with one another, conflicts ensue; when these are unified, thanks to the institution of standardized time, different futures are erased along with volatile futurity as such. Eurhythmics is the third way that ensures - in 
place of a full consensus - a minimum of coherence conducive to decision making, which amounts to saying that the future (especially that of democracies) is both like and unlike the past.

The value of moderation in the political thought of Innerarity is consistent with his vehement disapproval of the Schmittian view of politics as an activity predicated on intense oppositional group formations. Innerarity criticizes the 'lines of battle ... organized with startling simplicity between friends and enemies, or in a less bellicose but equally explicit version, into us versus them'. 'All that being said', he continues, 'does this truly represent reality? Are we currently living in a time of epic proportions? Do we think about and experience politics as if we were engaged in a heroic battle?' (p. 90) His answer to these questions is a clear 'no'. A postmetaphysical frame of reference does away with grand narratives as much as with dramatic political gestures that arise, with catastrophic consequences, from a black-and-white outlook on the world. Although he does not deal with this topic any more directly than in the above quotation, we might rightly imagine Innerarity arguing that the actors in Schmitt's world are completely desynchronized, or, better yet, that they achieve ideal in-group synchronization as a consequence of their stand-offish desynchronization with out-group members. In light of the emphasis on moderation, we can appreciate the author's singular definition of politics as 'a civilizing activity that serves to channel social conflicts in a reasonable way' (p. 98).

Of course, the precise outlines of 'a reasonable way' are far from being neutrally drawn once and for all but are, instead, concretized after a long history of the struggle for the right to fix the criteria for the optimal channeling of social conflicts. If we hold onto the value of moderation, we run the risk of disregarding the past and present political excesses it masks. The same applies to decisions that 'always reference the future' (p. 52). When it comes to the process of decision making, Innerarity proposes a precarious balance between balance and imbalance, between a meticulous analysis of alternatives - 'we must weigh the full range of options' (p. 52) - and a qualitative break with the continuum of temporality that frees decision makers to "establish something genuinely new in the world' (p. 53). Neither Kierkegaard's leap nor Schmitt's decisionism would do justice to this amalgam of gradualism and revolutionary change, even if the German jurist's notion of a sovereign decision on the exception approximates the idea of transcendence within immanence, or of politics born in (and breaking through) the lacunae of law. Besides theorizing decisions as the hybrids of inferential calculation and genuine novelty, Innerarity also conceives of life in 'every well-organized society' in terms of a mix of radical breaks and going with the flow, 'a give and take between innovative decisions and institutional stability' (p. 53). This model, too, is in surprising agreement with the Schmittian articulation of order and the exceptional events that punctuate it, including the event of constituting a new political regime made possible by the exercise in sovereign decision making. 
'The Future Taken Seriously' is the title of the introduction to the monograph under review, and at the same time an apt description of the text's main task, which is discharged at once elegantly and comprehensively. Besides the theories of decision, chronopolitical rhythms and political contingency that I have touched upon here, the reader is treated to robust accounts of intergenerational justice and responsibility, modern acceleration and collective hope (to name but a few salient topics). In each instance, Innerarity pays close attention to the multiple and at times clashing temporalities of technological innovation and adherence to tradition; political populism - and our obligations to future generations; as well as to fast decision making and relatively slow knowledge acquisition. The conclusions of each chapter provide us with invaluable tools for coping with the complexity of our world without either simplifying or getting lost in it. At its best, The Future and Its Enemies maintains alive the very future of political philosophy.

Michael Marder IKERBASQUE/Department of Philosophy, University of the Basque Country (UPV-EHU), 01006 Vitoria-Gasteiz, Spain 